\title{
Chemical Composition, Antimicrobial and Antioxidant Activities of Eugenia Dysenterica DC Essential Oil
}

\author{
Danielle C. S. de Oliveira a, b, Telma M. Kaneko a, Maria Cláudia M. Young c \\ Cynthia Murakami ${ }^{c}$, Inês Cordeiro ${ }^{c}$, Paulo Roberto H. Moreno ${ }^{\text {a }} b^{*}$ \\ ${ }^{a}$ Department of Pharmacy, University of São Paulo, São Paulo, Brazil \\ ${ }^{b}$ Institute of Chemistry, University of São Paulo, São Paulo, Brazil \\ ' Instituto de Botânica, São Paulo, Brazil
}

\begin{abstract}
Eugenia dysenterica DC is a native species from the Cerrado biome and can be found in several states of Brazil. This study evaluated the chemical composition, antimicrobial and antioxidant activities from the essential oils of a population collected in São Paulo state. Essential oils were obtained by conventional means, and their compositions were analyzed by GC-MS. Screening assays for antimicrobial activity were carried out by the microdilution method and the antioxidant potential was assessed by the DPPH scavenging method. The GC-MS analysis indicated that $52.63 \%$ of the essential oil is composed by oxygenated sesquiterpenes and the major compound is (-)-elema-1,3,11(13)-trien12 -ol $(24.86 \%)$. The antimicrobial assay indicated MIC $42.1 \mu \mathrm{g} / \mathrm{mL}$ for $S$. aureus and MIC $>10000$ $\mu \mathrm{g} / \mathrm{mL}$ for the other tested microorganisms, Gram negative bacteria and fungi. The oil showed an $\mathrm{IC}_{50}$ of $5.4 \pm 0.632 \mathrm{mg} / \mathrm{mL}$ for in the DPPH assay. The essential oil had a different chemical composition from previous studies. The essential oil did not present a potent antioxidant activity. However, it can be considered a promising antimicrobial agent against $S$. aureus.
\end{abstract}

\section{Keywords:}

Eugenia Dysenterica;

Essential Oil;

Antioxidant Activity;

Antimicrobial Activity;

GC-MS.

\section{Article History:}

Received: 18 September 2018

Accepted: $\quad 30$ October 2018

\section{1- Introduction}

Myrtaceae is an important plant family in Brazil, where approximately 1000 species are found [1], from these 211 are accounted for Cerrado biome [2]. These species are well known for its edible fruits and are also considered as a source for essential oils. Additionally, several species are traditionally used for medicinal purposes [3]. One of these Cerrado species, Eugenia dysenterica DC (also known as "cagaita" or "cagaiteira"), has its fruits widely consumed in this area, both in natura or as ingredient for jams and ice creams. The tree is also appreciated for landscaping, due to its numerous flowers, construction (wood) and tannery (barks) [4-5]. In the traditional medicine, its leaves are used to treat diarrhea and dysentery [6]. This activity was evaluated in the essential oil and ethanolic extract from the leaves. The essential oil presented antidiarrheic effect that seems to be linked with its capacity to alter the process of intestinal absorption and/or secretion [7]. The ethanolic extract decreased intestinal motility in induced diarrhea in rats. Therefore, it can be concluded that compounds present in the leaves can have a therapeutic effect in the treatment of diarrhea [8].

Another activity of leaf extract is the gastroprotective effect. Leaf extract could protect the gastric mucosa against ethanol/HCl-induced ulcer in mice and this effect seems to be related to the presence of the condensed tannins in the extract [9]. The extract also showed antiviral activity against simian rotavirus SA11 [10] and molluscicidal activity against Biomphalaria glabrata, intermediate host of schistosomiasis [11]. Besides the activities in the gastrointestinal tract, a recent study suggested that the essential oils of E. dysenterica leaves possess therapeutic potential in the prevention of neurodegenerative disorders, such as Alzheimer's disease [12]. The whole oil was able to inhibit the

\footnotetext{
* CONTACT: Prmoreno@iq.usp.br

DOI: http://dx.doi.org/10.28991/esj-2018-01160

(C) This is an open access article under the CC-BY license (https://creativecommons.org/licenses/by/4.0/).
} 
Acetylcholinesterase enzyme, which has been used in this disease treatment. The natural product was more potent than a drug commonly used (rivastigmine), $\mathrm{IC}_{50} 0.92$ and $1.87 \mu \mathrm{L} / \mathrm{mL}$ respectively. Caryophyllene oxide, the major constituent of oil in that study, was isolated and evaluated as well. This compound was even more potent than the essential oils and the $\mathrm{IC}_{50}$ value $(0.3 \mu \mathrm{L} / \mathrm{mL})$ was six times smaller than the reference drug.

Most research on the biological activities of E. dysenterica is related to the leaf extracts and little is found for essential oils. In this context and considering that this species can be found distributed in several states of Brazil (Bahia, Federal District, Goiás, Maranhão, Mato Grosso, Mato Grosso do Sul, Minas Gerais, Pará, Piauí, São Paulo and Tocantins) and considering that the populations differ chemically whenever geographical distance exceeds $120 \mathrm{~km}$ [13], the objective of this work is to evaluate the chemical composition, antimicrobial and antioxidant activity of the essential oil collected in the state of São Paulo.

\section{2- Materials and Methods}

\section{2-1-Plant Material}

Eugenia dysenterica DC leaves were collected at Reserva Biológica and Estação Experimental Fazenda Campininha, Mogi-Guaçu, SP, Brazil $\left(22^{\circ} 15^{\prime}\right.$ to $22^{\circ} 16^{\prime}$ Sand $47^{\circ} 8^{\prime}$ to $\left.47^{\circ} 12^{\prime} \mathrm{W}\right)$. Taxonomic identification was performed by Dr. Inês Cordeiro from Instituto de Botânica de São Paulo, where a voucher specimen has been deposited in its Herbarium (Brumati 213).

\section{2-2-Essential Oil Extraction}

E. dysenterica leaves were dried at room temperature and the essential oil extraction was performed by steam distillation in a Clevenger-type apparatus for 3 hours. After the extraction, the oils were collected, dried over anhydrous sodium sulfate, weighted and kept at $-25^{\circ} \mathrm{C}$ until the analysis. The yield was calculated based on plant dry weight (w/w).

\section{2-3-CG-MS Analysis}

Qualitative analysis of essential oils from the leaves of E. dysenterica was performed in an Agilent6890 Series GC (Agilent, Santa Clara, CA, USA) interfaced with a 5973 series quadrupole MS detector (Agilent, Santa Clara, CA, USA), equipped with a DB-5 column $(30 \mathrm{~m} \times 0.25 \mathrm{~mm}$ i.d. $\times 0.25 \mu \mathrm{m})$ (Agilent J\&W, Santa Clara, CA, USA). Chromatography conditions were as follows; over temperature: initially held at $40{ }^{\circ} \mathrm{C}$ for $1 \mathrm{~min}$ and subsequently increased to $240{ }^{\circ} \mathrm{C}$ at $3{ }^{\circ} \mathrm{C} / \mathrm{min}$; carrier gas: $\mathrm{He}$ at a flow rate of $1 \mathrm{~mL} / \mathrm{min}$; injector and detector temperature: $250{ }^{\circ} \mathrm{C}$, electron ionization: 70 $\mathrm{eV}$. The components were identified by comparing retention indices (evaluated in relation to the retention times of a series of $n$-alkanes) and mass spectra with those reported in the literature $[14,15]$.

\section{2-4-Antimicrobial Activity}

The antimicrobial activity was evaluated using microdilution method [16] against the microorganisms Candida albicans (ATCC 10231), Escherichia coli (ATCC 8739), Pseudomonas aeruginosa (ATCC 9027), Staphylococcus aureus (ATCC 6538) and Aspergillus brasiliensis (ATCC 16404). The inoculum was prepared from microbial suspension (standardized in $0.9 \%$ saline solution and McFarland turbidity scale) and liquid culture media (TSB for the bacteria and SDB for the yeast and fungi). The final concentration was $2 \times 103$ colony-forming units (CFU)/mL in each well of the microplate (Corning, New York, NY, USA). Dilutions of the essential oil were prepared using the solvent $\mathrm{DMSO} / \mathrm{MeOH}$ (1: 1). Growth (inoculum), sterility (culture media) and solvent (DMSO/ $\mathrm{MeOH}$ ) controls were also performed. The incubation period was $48 \mathrm{~h}$ at $25{ }^{\circ} \mathrm{C}$ for $\mathrm{C}$. albicans, 72 hours at $25{ }^{\circ} \mathrm{C}$ for A. brasilensis and $24 \mathrm{~h}$ at 35 ${ }^{\circ} \mathrm{C}$ for the other microorganisms. The plates were read in a spectrophotometer (BiotekSynergy HT Biotek, Winooski, VT, USA) at $630 \mathrm{~nm}$. For A. brasiliensis the determination of the inhibition was visual, considering the presence or absence of growth. Minimum inhibitory concentration (MIC) was considered the lowest dilution value of essential oil that was able to totally inhibit microbial growth.

\section{2-5-In Vitro Antioxidant Activity}

Antioxidant activity was determined by 2,2-diphenyl-1-picrylhydrazyl (DPPH) radical scavenging method [17]. The assay was performed on 96-well microplates (Corning, New York, NY, USA) using DPPH methanol solution at the final well concentration of $0.06 \mathrm{mg} / \mathrm{mL}$. The essential oil was solubilized in methanol and a serial dilution was made. Quercetin was used as positive control. The DPPH solution was considered the sample control, methanol was considered the blank sample. The reaction occurred for 30 minutes, protected from the light, then the plates were read at $517 \mathrm{~nm}$ in a spectrophotometer (Biotek Synergy HT Biotek, Winooski, VT, USA). IC50 value calculation was based on the equation of the linear regression curves of the inhibition for each sample. 


\section{3- Results}

\section{3-1-Chemical Composition of Essential Oil}

The leaf essential oil from E. dysenterica presented a yield of $0.064 \% \pm 0.005$. E. dysenterica essential oil consisted of at least 31 compounds from which 19 were identified. The amount of co-eluting compounds in the sesquiterpene range made it difficult to atribute a structure to all the peaks. The compounds, their retention indices, and the percentage of each oil constituent are listed in Table 1.

Table 1. Chemical composition of the essential oil from $E$. dysenterica leaves.

\begin{tabular}{|c|c|c|c|}
\hline Compounds & $\mathbf{R} \mathbf{I}^{\mathbf{a}}$ & RI (lit.) ${ }^{\mathbf{b}}$ & $\%$ \\
\hline linalool & 1098 & 1096 & 0.67 \\
\hline$\alpha$-terpineol & 1193 & 1188 & 1.24 \\
\hline$\alpha$-copaene & 1373 & 1376 & 3.82 \\
\hline$\beta$-caryophyllene & 1414 & 1419 & 1.59 \\
\hline$\alpha$-humulene & 1452 & 1454 & 2.81 \\
\hline$\alpha$-bulnesene & 1510 & 1509 & 0.56 \\
\hline$\delta$-cadinene & 1515 & 1523 & 5.33 \\
\hline N.I. & 1531 & - & 0.59 \\
\hline$\alpha$-calacorene & 1537 & 1545 & 2.07 \\
\hline N.I. & 1545 & - & 0.95 \\
\hline N.I. & 1550 & - & 1.27 \\
\hline N.I. & 1565 & - & 0.77 \\
\hline caryophyllenyl alcohol & 1571 & 1572 & 2.57 \\
\hline caryophyllene oxide & 1577 & 1583 & 2.46 \\
\hline N.I. & 1582 & - & 0.96 \\
\hline N.I. & 1590 & - & 4.61 \\
\hline N.I. & 1595 & - & 6.23 \\
\hline ledol & 1599 & 1602 & 1.52 \\
\hline humulol & 1603 & 1618 & 1.91 \\
\hline junenol & 1607 & 1619 & 6.24 \\
\hline$\alpha$-corocalene & 1612 & 1623 & 1.02 \\
\hline N.I. & 1616 & - & 0.92 \\
\hline muurola-4,10(14)-dien-1- $\beta$-ol & 1624 & 1631 & 3.89 \\
\hline N.I. & 1628 & - & 2.60 \\
\hline (-)-elema-1,3,11(13)-trien-12-ol & 1637 & 1673 & 24.86 \\
\hline N.I. & 1657 & - & 9.01 \\
\hline germacra-4(15),5,10(14)-trien-1- $\alpha$-ol & 1665 & 1686 & 0.62 \\
\hline N.I. & 1669 & - & 5.67 \\
\hline N.I. & 1678 & - & 1.56 \\
\hline amorpha-4,9-dien-2-ol & 1692 & 1700 & 0.59 \\
\hline 10-nor-calamenen-10-one & 1695 & 1702 & 1.09 \\
\hline Total identified & & & 64.86 \\
\hline N.I. & & & 35.14 \\
\hline Oxygenated monoterpenes & & & 1.91 \\
\hline Oxygenated sesquiterpenes & & & 45.75 \\
\hline Sesquiterpenes hydrocarbons & & & 17.2 \\
\hline
\end{tabular}

${ }^{\mathrm{a}}$ Retention index on DB-5 column; ${ }^{\mathrm{b}}$ Literature values $[14,15]$. N.I. $=$ not identified. 


\section{3-2-Antimicrobial Activity}

The antimicrobial activities of the essential oil of E. dysenterica were evaluated against $S$. aureus, E. coli, P. aeruginosa, C. albicans and A. brasiliensis. The most sensitive organism was $S$. aureus, presenting the lowest MIC (minimum inhibitory concentration) value.The MIC value for all the microorganisms are presented in Table 2. The values on the table correspond to thefinal well concentration.

Table 2. Minimum inhibitory concentration (MIC) of the essential oil from $E$. dysenterica leaves.

\begin{tabular}{cc}
\hline Microorganism & $\mathbf{M I C} \pm \mathbf{S D}(\boldsymbol{\mu g} / \mathbf{m L})$ \\
\hline S. aureus & $42.1 \pm 1.92$ \\
E. coli & $>10,000$ \\
P. aeruginosa & $>10,000$ \\
C. albicans & $>10,000$ \\
A. brasiliensis & $>10,000$ \\
\hline
\end{tabular}

SD - Standard deviation

\section{3-3- In Vitro Antioxidant Activity}

The essential oil antioxidant activity was expressed as half maximal inhibitory concentration $\left(\mathrm{IC}_{50}\right)$ of the stable radical DPPH and the results are presented in Table 3. The concentration values presented correspond to the final well concentration.The antioxidant potential was compared to that obtained for quercetin, as positive control.

Table 3. Antioxidant activity ( IC $\left._{50}\right)$ by DPPH method of the essential oil from $E$. dysenterica leaves.

\begin{tabular}{lc}
\hline Sample & $\mathbf{I C}_{50} \pm \mathbf{S D}(\mathbf{m g} / \mathbf{m L})$ \\
\hline E. dysenterica & $5.4 \pm 0.6$ \\
& $\mathbf{I C}_{50} \pm \mathbf{S D}(\boldsymbol{\mu g} / \mathbf{m L})$ \\
Quercetin $^{\mathrm{a}}$ & $4.3 \pm 0.9$ \\
\hline${ }^{2}$ &
\end{tabular}

\section{4- Discussion}

The yield obtained for the leaf essential oil from E. dysenterica collected in the São Paulo Cerrado $(0.064 \%)$ was much lower than those previously found in other locations such as Piauí 1.48\% [12], Minas Gerais, 0.34\% [7], Brasília $0.25 \%$ [18] and Goiás $0.15 \%$ [6]. The chemical analysis allowed to identify 19 compounds and most of them are sesquiterpenes, divided in oxygenated $45.75 \%$ and hydrocarbons $17.2 \%$. This result was similar to previous studies, where sesquiterpenes were the main class [6, 7, 12, 13, 17-19]. However, sesquiterpene hydrocarbons were predominant in most of the studies. Variations in essential oil yields and chemical composition among different populations can be caused by several factors such as the season of the year in which the collection occurred, the nutrients present in the soil [20] as well as the distance between the populations [13].

$\beta$-caryophyllene (15-37\%), caryophyllene oxide (66.3\%) and cis- $\beta$-ocimene $(19.14 \%)$ were the major compounds previously identified. In the present study, cis- $\beta$-ocimene was not found and $\beta$-caryophyllene was present in very low amounts (1.59\%), and even considering its oxidation product (caryophyllene oxide, $2.46 \%$ ), this compound still would not reach the previous rates. The major compound found in our study was the oxygenated sesquiterpene (-)-elema1,3,11(13)-trien-12-ol (Fig. 1), with almost $25 \%$ of the total essential oil composition. This compound has already been isolated from the wood essential oil of Thujopsis dolobrata Sieb et Zucc, an endemic species from Japan, demonstrating inhibitory activity for $\mathrm{Na}^{+} / \mathrm{K}^{+}$-ATPase and lipopolysaccharide-induced nitric oxide production and it may also be an alternative to the treatment of allergic disorders mediated by $\operatorname{IgE}[21]$. 


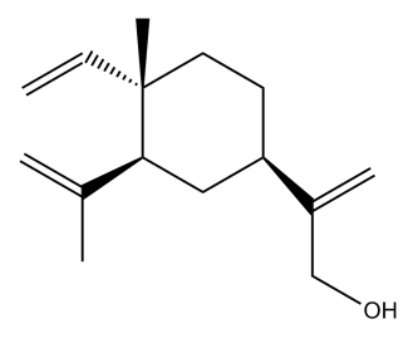

Figure 1. Chemical structure of (-)-elema-1,3,11(13)-trien-12-ol.

The essential oil of $E$. dysenterica was evaluated for its antimicrobial activity against five microorganisms. At the concentration of $10,000 \mu \mathrm{g} / \mathrm{mL}$, the essential oil was not able to totally inhibit the growth of $E$. coli, $P$. aeruginosa, $C$. albicans and A. brasiliensis. The result obtained for $C$. albicans agrees with previous studies [6], however the other microorganisms had not yet been evaluated. Normally, only plant extracts that can completely inhibit microbial growth at concentrations below $100 \mu \mathrm{g} / \mathrm{mL}$ are considered interesting for the development of new antimicrobial agents [16]. $S$. aureus was the most sensitive microorganism, with a minimum inhibitory concentration (MIC) of $42.1 \mu \mathrm{g} / \mathrm{mL}$. Gram negative bacteria have a cell wall composed of mucopolysaccharides that prevents the contact of the hydrophobic essential oil constituents with the bacterial cell membrane, therefore, the essential oils generally are more active against gram positive bacteria [7]. The activity found for S. aureus with the E. dysenterica oil was more potent than the MIC's reported for other Eugenia species, such as E. adstringens Cambess (119.2 $\mu \mathrm{g} / \mathrm{mL})$, E. beaurepaireana (Kiaersk) D. Legrand $(1,110 \mu \mathrm{g} / \mathrm{mL})$ and E. brasiliensis Lam. (156.2 $\mu \mathrm{g} / \mathrm{mL})[16]$.

Biological redox reactions and environmental factors (pollution, smoke, sun light) generate free radicals and the excess of this substances can cause damage in the living organisms [22]. Therefore, free radical scavenging agents find application in the treatment of diseases such as atherosclerosis and cancer and in the decreasing of the aging process. They also can be useful in the food industry, increasing the shelf-life of food products [23]. Due to the abundance of oxygenated compounds, the antioxidant activity of the essential oil was also evaluated. The E. dysenterica essential oil was able to quench the DPPH radical with an $\mathrm{IC}_{50}$ of $5.4 \mathrm{mg} / \mathrm{mL}$. Compared with other Eugenia species, such as $E$. uniflora $\left(\mathrm{IC}_{50}=833 \mu \mathrm{g} / \mathrm{mL}\right)$ [24] and E. caryophyllata $\left(\mathrm{IC}_{50}=0.2 \mu \mathrm{g} / \mathrm{mL}\right)$ [25], E. dysenterica presented the weaker activity. Using as reference Gingko biloba (Egb 761) extract, used medicinally duo to its recognized antioxidant activity $\left(\mathrm{IC}_{50}=44.7 \mu \mathrm{g} / \mathrm{mL}\right)$ [26], it is possible to state that the essential oil of E. dysenterica cannot be considered a potent antioxidant agent.

\section{5-Conclusion}

The essential oil was composed for the most part by oxygenated sesquiterpenes. This result was different from most of the previous studies accomplished in the other states of the country and might be an indication of different chemotypes for this species. The antioxidant activity can be considered weak comparing to other Eugenia species and Gingko biloba. However, this essential oil presented a potent activity against $S$. aureus making this oil a potential antimicrobial agent against this microorganism. Further studies evaluating the antibacterial effect including synergism with other antimicrobials can be interesting.

\section{6- Funding}

This study was financed in part by the Coordenação de Aperfeiçoamento de Pessoal de Nível Superior - Brasil (CAPES) - Finance Code 001.

\section{7- Conflict of Interest}

The authors declare no conflict of interest.

\section{8- References}

[1] Landrum, L.R.; Kawasaki, M.L. "The genera of Myrtaceae in Brazil: an illustrated synoptic treatment and identification keys." Brittonia 49, no.4 (1997):508-536 doi:10.2307/2807742.

[2] Vieira, R.F.; Costa, T.S.A.; Silva, D.B.; Ferreira, F.R.; Sano, S.M. "Frutas nativas da região Centro-Oeste do Brasil, First Edition" (2006).

[3] Ramos, M.F.S; Siani, A.C.; Souza, M.C.; Rosas, E.C.; Henriques, M. G. M. O. “Avaliação da atividade antiinflamatória dos óleos essenciais de cinco espécies de Myrtaceae”. Revista Fitos 2, no.2 (2006):58-66. 
[4] Mendonça, R.S.; Chaves, L,J.; Naves, R.V. "Caracterização de frutos e árvores de cagaita (Eugenia dysenterica DC) no sudeste do estado de Goiás, Brasil.” Revista Brasileira de Fruticultura 23, no.2 (2001):330-334. doi: 10.1590/S0100-29452001000200026.

[5] Almeida, S.P.; Proença, C.E.B.; Sano, S.M.; Ribeiro, J.F. “Cerrado: espécies vegetais úteis, First Edition.” (1998).

[6] Costa, T.R.; Fernandes, O.F.L.; Santos, S.C.; Oliveira, C. M. A.; Lião, L.M.; Ferri, P.H.; Paula, J.R.; Ferreira, H.D.; Sales, B.H.N.; Silva, M.R.R. "Antifungal activity of volatile constituents of Eugenia dysenterica leaf oil." Journal of Ethnopharmacology 72, no.1-2 (2000):111-117. doi: 10.1016/S0378-8741(00)00214-2.

[7] Galheigo, M.R.U.; Prado, L.C.S.; Mundin, A.M.M.; Gomes, D.O.; Chang, R.; Lima, A.M.C.; Canabrava, H.A.N.; Silva, L.B.B. "Antidiarrhoeic effect of Eugenia dysenterica DC (Myrtaceae) leaf essential oil” Natural Product Research 30, no. 10 (2016):1182-1185. doi: 10.1080/14786419.2015.1043633.

[8] Lima, T.B.; Silva, O.N.; Silva, L.P.; Rocha, T.L.; Sá, M.F.G.; Franco, O.L.; Leonardecz, E. "In Vivo Effects of Cagaita (Eugenia dysenterica DC) Leaf Extracts on Diarrhea Treatment." Evidence-Based Complementary Alternative Medicine 2011, (2011). doi:10.1155/2011/309390.

[9] Prado, L.C.S.; Silva, D.B.; Silva, G.L.O.; Hiraki, K.R.N.; Canabrava, H.A.N.; Silva, L.B.B. "The Gastroprotective Effects of Eugenia dysenterica (Myrtaceae) Leaf Extract: The Possible Role of Condensed Tannins." Biological \& Pharmaceutical Bulletin 37, no.5 (2014):722-730. doi: 10.1248/bpb.b13-00514.

[10] Cecílio, A.B.; Faria, D.B.; Oliveira, P.C.; Caldas, S.; Oliveira, D.A.; Sobral, M.E.G.; Maria Duarte, M.G.R.; Souza Moreira, C.P.S.; Cláudia Gontijo Silva, C.G.; Almeida, V.L. "Screening of Brazilian medicinal plants for antiviral activity against rotavirus.” Journal of Ethnopharmacology 141, no.3 (2012):975-981. doi:10.1016/j.jep.2012.03.031.

[11] Bezerra, J.C.B.; Silva, I.A.; Ferreira, H.D.; Ferri, P.H.; Santos, S.C. "Molluscicidal activity against Biomphalaria glabrata of Brazilian Cerrado medicinal plants.” Fitoterapia 73, no.5 (2002):428-430. doi:10.1016/S0367-326X(02)00121-1.

[12] Feitosa, C.M.; Barbosa, A.R.; Melo, C.H.S.; Freitas, R.M.; Fontes, J.E.N.; Coista, E.V.; Rashed, K.N., Júnior, J.S.C. "Antioxidant and anticholinesterase activities of the essential oil of Eugenia dysenterica DC." African Journal of Pharmacy and Pharmacology 11, no.19 (2017):241-249. doi: 10.5897/AJPP2015.4438.

[13] Vilela, E.C.; Carvalho, T.C.; Duarte, A.R.; Naves, R.R.; Santos, S.C.; Seraphin, J.C.; Ferri, P.H. "Spatial Structure of Eugenia dysenterica Based on Essential Oil Chemovariations and Implications for Conservation and Management of the Genetic Diversity of its Populations." Journal of the Brazilian Chemical Society 23, no.10 (2012):1776-1782. doi:10.1590/S0103-50532012005000043.

[14] Adams, R.P. "Identification of Essential Oil Components by Gas Chromatography/Mass Spectrometry, Fourth Edition.” (2007).

[15] NIST (National Institute of Standards and Technology) U.S. Department of Commerce. Accessed on 14 June 2016. https://www.nist.gov/

[16] Moreno, P.R.H.; Costa-Issa, F.I.C.; Rajca-Ferreira, A.K.; Pereira, M.A.A.; Kaneko, T.M. "Native Brazilian plants against nosocamial infections: A critical review on their potential and the antimicrobial methodology." Current Topics in Medicinal Chemistry 13, no.24 (2013):3040-3078. doi: 10.2174/15680266113136660219.

[17] Brand-Williams, W; Cuvelier, M.E.; Berset, C. "Use of a free radical method to evaluate antioxidant activity." Food Science and Technology 28, no. 1 (1995):25-30. doi:10.1016/S0023-6438(95)80008-5.

[18] Paulo, P.R.S. “Óleos essenciais de espécies de eugenia do cerrado: composições químicas sazonais, modificações químicas no $\beta$-cariofileno e avaliação da atividade acaricida.” Doctoral degree, Universidade de Brasília, Distrito Federal, Brazil, (2015).

[19] Duarte, A.R.; Naves, R.R.; Santos, S.C; Seraphin, J.C.; Ferri, P.H. "Seasonal Influence on the Essential Oil Variability of Eugenia dysenterica." Journal of the Brazilian Chemical Society 20, no.5 (2009):967-974. doi: 10.1590/S0103-50532009000500023

[20] Duarte, A.R.; Naves, R.R.; Santos, S.C; Seraphin, J.C.; Ferri, P.H. "Genetic and Environmental Influence on Essential Oil Composition of Eugenia dysenterica." Journal of the Brazilian Chemical Society 21, no.8 (2010):1459-1467. doi: 10.1590/S0103-50532010000800008.

[21] Kim,C.H.; Lee, T.; Oh, I.; Nam, K.W.; Kim, K.H.; Oh, K.B.; Shin, J.; Mar, W. "Mast Cell Stabilizing Effect of (-)-Elema1,3,11(13)-trien-12-ol and Thujopsene from Thujopsis dolabrata Is Mediated by Down-Regulation of Interleukin-4 Secretion in Antigen-Induced RBL-2H3 Cells" Biological and Pharmaceutical Bulletin 36, no.3 (2013):339-345. https://doi.org/10.1248/bpb.b12-00375.

[22] Anthony, K.P.; Deolu-Sobogun, S.A.; Saleh, M.A. "Comprehensive assessment of antioxidant activity of essential oils.” Journal of Food Science 77, no.8 (2012):839-843. https://doi.org/10.1111/j.1750-3841.2012.02795.x.

[23] Baratta, M.T.; Dorman, D.: Deans, S.G.; Figueiredo, C.; Barroso, J.G.; Ruberto, G. “Antimicrobial and antioxidant properties of 
some commercial essential oils." Flavour and Fragrance Journal 13, no.4 (1998):235-244. doi: 10.1002/(SICI)1099-1026(1998070)13:4<235::AID-FFJ733>3.0.CO;2-T.

[24] Victoria, F.N.; Lenardão, E.J.; Savegnago, L.; Perin, G.; Jacob, R.G.; Alves, D.; Silva, W.P.; Motta A.S.; Nascente, P.S. "Essential oil of the leaves of Eugenia uniflora L.: Antioxidant and antimicrobial properties." Food and Chemical Toxicology 50, no.8 (2012):2668-2674. doi: 10.1016/j.fct.2012.05.002.

[25] Chaieb, K.; Zmantar, T.; Ksouri, R.; Hajlaoui, H.; Mahdouani, K.; Abdelly, C.; Bakhrouf, A. "Antioxidant properties of the essential oil of Eugenia caryophyllata and its antifungal activity against a large number of clinical Candida species.." Mycoses 50, no.5 (2007):403-406. doi: 10.1111/j.1439-0507.2007.01391.x.

[26] Mensor, L.L.; Menezes, F.S.; Leitão, G.G; Reis, A.S.; Santos, T.C.; Coube, C.S.; Leitão, S.G. "Screening of Brazilian plant extracts for antioxidant activity by the use of DPPH free radical method." Phytotherapy research 15, no.2 (2001):127-130. doi:10.1002/ptr.687. 